Article

\title{
Grassland Dynamics and the Driving Factors Based on Net Primary Productivity in Qinghai Province, China
}

\author{
Xiaoxu Wei ${ }^{1,2}$, Changzhen Yan ${ }^{1, *}$ and Wei Wei ${ }^{3}$ \\ 1 Key Laboratory of Desert and Desertification, Northwest Institute of Eco-Environment and Resources, \\ Chinese Academy of Sciences, Lanzhou 730000, China; weixiaoxu@lzb.ac.cn \\ 2 University of Chinese Academy of Sciences, Beijing 100049, China \\ 3 College of Geographic and Environmental Science, Northwest Normal University, Lanzhou 730070, China; \\ weiweigis2006@126.com \\ * Correspondence: yancz@lzb.ac.cn
}

Received: 20 November 2018; Accepted: 27 January 2019; Published: 2 February 2019

\begin{abstract}
Qinghai province is an important part of the Tibetan Plateau, and is characterized by extremely fragile ecosystems. In the last few decades, grasslands in this province have been influenced profoundly by climate change, as well as human activities. Here, we use the Carnegie-Ames-Stanford Approach (CASA) model to assess the dynamics of temperate steppe, alpine steppe, temperate meadow, alpine meadow, sparse grassland and herbaceous wetland via actual net primary productivity $\left(\mathrm{NPP}_{\mathrm{a}}\right)$. Our findings showed that: (1) From 2001 to 2016, the average $\mathrm{NPP}_{\mathrm{a}}$ in Qinghai province showed a fluctuation presented a generally increasing trend. The mean value of $\mathrm{NPP}_{\mathrm{a}}$ was $114.27 \mathrm{~g} \mathrm{C} \mathrm{m}^{-2}$ year ${ }^{-1}$, and the increase rate was $0.47 \mathrm{~g} \mathrm{C} \mathrm{cm}^{-2}$ year $^{-1}$. (2) There were $\mathrm{NPP}_{\mathrm{a}}$ increase rate discrepancies among the six typical grassland biomes. Herbaceous wetland had the highest change rate, closely followed by alpine steppe, temperate steppe, alpine meadow, temperate meadow and sparse grassland. (3) The largest area of restoration mainly impacted by climate change reached $47.08 \%$ of the total grassland area, with human activities accounting for $21.74 \%$. By contrast, the deteriorated area induced by human activities accounted for $9.78 \%$ of the total grassland. (4) Temperature may have been a greater factor than precipitation in driving grassland change during the study period. Decreasing grazing intensity and implementing effective protection measures were favorable to grassland restoration.
\end{abstract}

Keywords: Net primary productivity (NPP); Climate change; Human activities; Grassland restoration

\section{Introduction}

Grasslands as an important part of the terrestrial ecosystems account for 30\% of the global land area [1]. The dynamics of grassland have a profound impact on ecology and carbon cycling [2], as well as interacting with climate change [3]. Net primary production (NPP) is the net amount of carbon captured by vegetation through photosynthesis per unit area and time, and varies with vegetation growing conditions [4]. NPP was considered as an indispensable indicator to measure ecosystem responses to climate change [5], and was also used to evaluate the impacts of human activities on grassland in previous studies [1,6]. In recent years, many studies of NPP have been conducted, which explored the long term monitoring of grassland dynamics and its driving forces. It was reported that the vegetation recovery was obvious in more than one decade in the Qinghai-Tibet Plateau, mostly due to the implementation of a series of ecological restoration project, climate change [7,8]. From 2001 to 2013 , the restored area and the deteriorated area in the Qinghai-Tibet Plateau accounted for $38.8 \%$ and $61.2 \%$ of the total grassland, respectively [9]. NPP was responsive to phenological dynamics in the 
Tibetan Plateau, China [10]. From 1982 to 2000, the climate conditions were favorable to vegetation recovery in the Three-River Source Region, whereas human activities had a weaker negative impact on vegetation growth; after 2000, human activities contributed to vegetation recovery, and climate conditions had a negative impact on vegetation growth [4]. It was investigated that the restoration for alpine grasslands was significant in recent years, since the ecological restoration project Grazing Withdrawal was carried out in the Qinghai-Tibet Plateau [1]. Accordingly, many models have been developed rapidly and were widely used, including the Carnegie Ames Stanford Approach (CASA) model [5], an improved CASA model [11], the Thornthwaite Memorial model [12], a multi-factor model [13]. So far, however, few studies have made comparisons among different grassland types in Qinghai province. Not only the actual NPP $\left(\mathrm{NPP}_{\mathrm{a}}\right)$ changing trend for each grassland type in time and space, also the driving forces on each grassland type remains unclear.

Qinghai province is an important ecological barrier of the Tibetan Plateau, since it has abundant grasslands resources, special location and crucial ecological functions, and is currently confronted by severe grassland degradation [14]. The grassland ecosystem is extremely sensitive to a set of factors, such as temperature, precipitation, sunshine duration and grazing density and other socio-economic factors [15]. Therefore, it is of great importance to monitor the variations of grassland NPP, and identify the differences among six grassland types, then analyze the driving forces in Qinghai province [11].

In this study, the objectives were to (1) accurately simulate the spatiotemporal evaluation of grassland NPP in Qinghai province from 2000 to 2016; (2) distinguish the effects of various driving factors on grassland dynamics; (3) identify the differences among temperate steppe, alpine steppe, temperate meadow, alpine meadow, sparse grassland and herbaceous wetland; (4) provide a theoretical basis for grassland recovery and the effects of ecosystem protection projects.

\section{Materials and Method}

\subsection{Study Area}

Qinghai province $\left(89^{\circ} 35^{\prime}-103^{\circ} 04^{\prime} \mathrm{E}, 31^{\circ} 39^{\prime}-39^{\circ} 19^{\prime} \mathrm{N}\right)$ is located in the northeast of the Tibetan Plateau, covering a total area of approximately $69.67 \times 10^{4} \mathrm{~km}^{2}$ (Figure 1). The terrain range is relatively pronounced, showing decreasing elevation from higher mountains in the northwest to the lower ones in the southeast. The elevation of Qinghai province has a gradient from high in the west to low in the east. The region is not only encircled by huge mountain ranges, also valleys and basins along with mountain ranges interlaced together. The administrative regions were as follows: the regions around Qinghai Lake and Qilian mountains, with livestock as the dominant industry; eastern agricultural regions concentrate in the transition zone from the Loess Plateau to Tibetan Plateau and northwest arid area, with an altitude between 1700 and $3500 \mathrm{~m}$ and under good weather condition; the Qaidam basin is located in the northwest, and is characterized by low air temperature, rare rainfall and strong solar radiation, forming arid and extremely arid natural landscape; pastoral areas, located in the hinterland of the Tibetan Plateau with the elevation above $4200 \mathrm{~m}$, is known as the source region of Yellow river, Lancang river and Yangtze river (Three-River Headwaters region). The annual precipitation is below $800 \mathrm{~mm}$ in many local areas of Qinghai province, decreasing from southeast to northwest, while the annual precipitation in the Qaidam basin is lowest, ranging from $17 \mathrm{~mm}$ to $182 \mathrm{~mm}$. The major vegetation type is grassland, accounting for $59.13 \%$ of the total area. The growing season of grasslands starts in early May and ends in late September [9]. The Tibetans are the most dominant residents in this region, who depend on animal husbandry for their livelihood. 


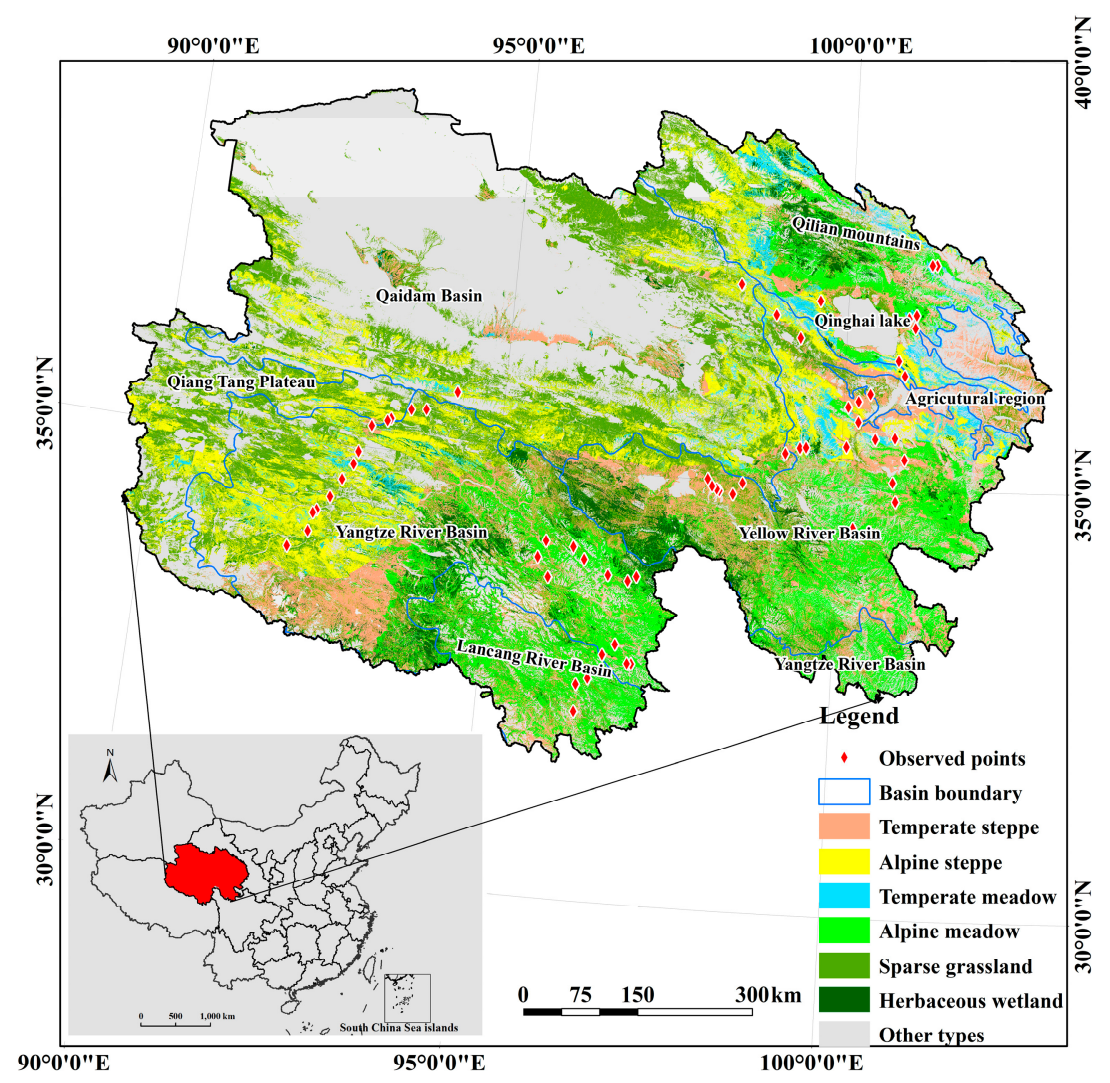

Figure 1. Location of the study area and spatial distribution of six grassland types in Qinghai province.

\subsection{Data and Processing}

The monthly climate datasets, including precipitation, ground vapor pressure, temperature, solar radiation, sunshine duration and relative humidity data were derived from 69 climatological stations in Qinghai and its surrounding provinces (http://cdc.cma.gov.cn), covering the period 2001-2016. The monthly raster images were generated from the meteorological data by using the Kriging interpolation method [16]. In order to be consistent with the MODIS NDVI data, we resampled the interpolated images to a spatial resolution of $500 \mathrm{~m}$. Then, the WGS-84 datum and Albers equal-area conical projection was applied for all raster images.

The Moderate Resolution Imaging Spectroradiometer (MODIS) dataset used in this study was the MOD09A1 (http:/ / earthdata.nasa.gov/), which were transformed from their original sinusoidal projection to WGS_1984_Albers projection by using the MODIS Reprojection Tool (MRT). Reflectances of the red band and the near-infrared band were used to calculate the normalized difference vegetation index (NDVI) for the period 2001-2016. The monthly NDVI images were obtained from the 8-day NDVI data by using the maximum-value compositing (MVC) method.

Landsat images (Landsat 8 OLI) covering the whole Qinghai province with spatial resolution of $30 \mathrm{~m}$, derived from USGS (United States Geological Survey), were used as data source to extract six grassland types (i.e., temperate steppe, alpine steppe, temperate meadow, alpine meadow, sparse grassland and herbaceous wetland) in 2015. The object-oriented classification approach provided by eCognition software and manual editing method with the help of Google Earth high resolution images were used to identify the patterns of six grassland types. The classification errors were corrected in ArcMap 10.3 through ground truth survey. The accuracy of data classification could reach $87.71 \%$ according to the independent field samples for validation. The areas of temperate steppe, alpine steppe, temperate meadow, alpine meadow, sparse grassland and herbaceous wetland in Qinghai province were $76159.79 \mathrm{~km}^{2}, 73084.75 \mathrm{~km}^{2}, 24074.89 \mathrm{~km}^{2}, 83202.19 \mathrm{~km}^{2}, 125236.19 \mathrm{~km}^{2}$ 
and $30067.86 \mathrm{~km}^{2}$, accounting for $19.00 \%, 17.74 \%, 5.84 \%, 20.20 \%, 30.41 \%$ and $7.30 \%$ of the total grassland area, respectively.

The livestock dataset of the period 2001-2016 was obtained from Qinghai statistical yearbook.

In our study, a total of 62 grassland field survey of the above ground biomass (AGB), derived from the sampling sites (Figure 1), were converted to the observed NPP data. Then the NPPa were validated by the observed NPP [17]. The AGB was measured in early August from 2001 to 2004, when grasses reached their most thriving growing period [9]. At each grassland site $(10 \times 10 \mathrm{~m})$, the grassland biomass in five quadrates $(1 \times 1 \mathrm{~m})$ was harvested, all the biomass samples were oven-dried in a vacuum oven at $65^{\circ} \mathrm{C}$ for 48 hours to remove the moisture. The weights of all the biomass samples were measured to the approximate $0.01 \mathrm{~g}$. Then the unit of oven-dried biomass $\left(\mathrm{g} \mathrm{m}^{-2}\right)$ was transformed into a carbon unit $\left(\mathrm{g} \mathrm{C} \mathrm{m}^{-2}\right.$ year $\left.{ }^{-1}\right)$ by multiplying the coefficient of 0.48 [18]. It was demonstrated that aboveground biomass represented aboveground NPP, which accounted for approximately $50 \%$ of the total NPP [19]. According to it, we calculated observed NPP from measured biomass. The simulated $\mathrm{NPP}_{\mathrm{a}}$ was correlated with the observed NPP significantly $\left(\mathrm{R}^{2}=0.79, \mathrm{p}<0.01\right)$ (Figure 2$)$.

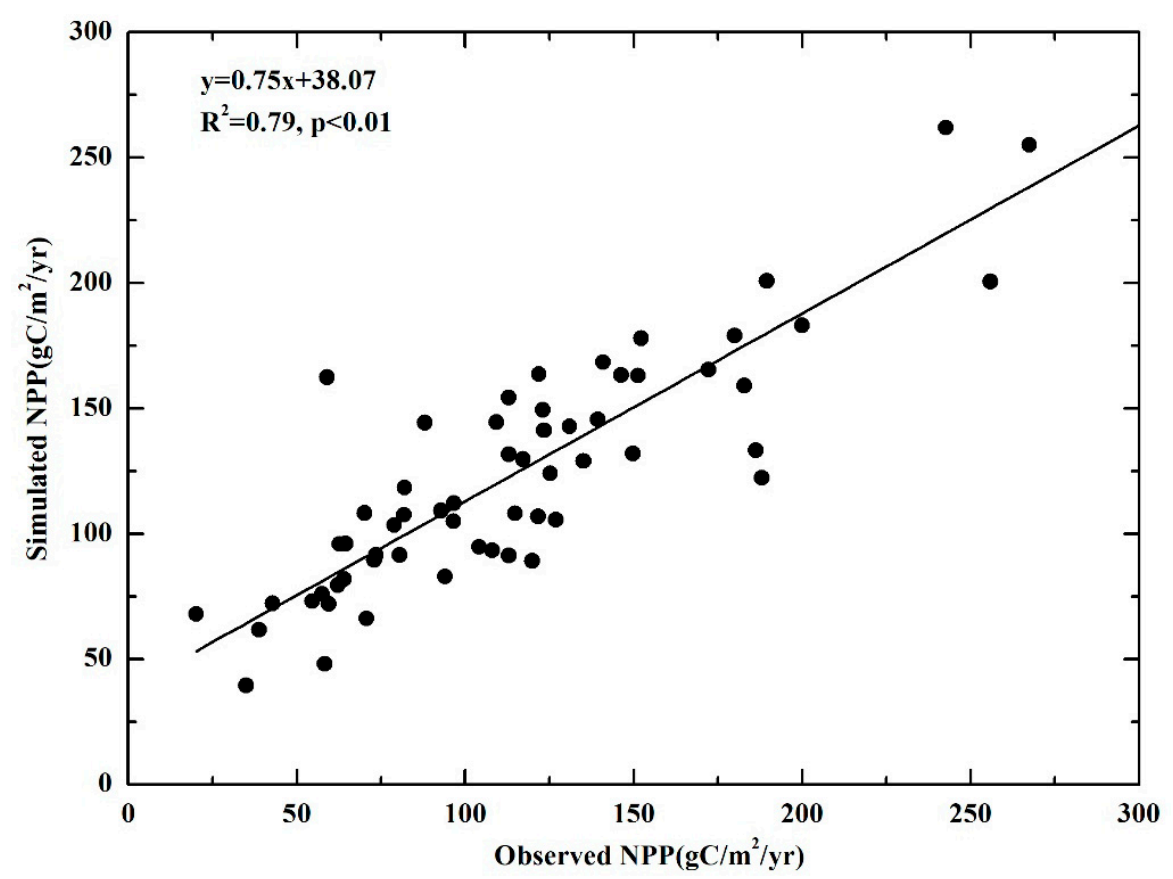

Figure 2. Comparisons of simulated net primary productivity (NPP) from the Carnegie-Ames-Stanford Approach (CASA) model and observed NPP.

\subsection{Methods}

\subsubsection{Calculating $\mathrm{NPP}_{\mathrm{a}}, \mathrm{NPP}_{\mathrm{p}}$, and $\mathrm{NPP}_{\mathrm{h}}$}

The CASA model is the light-use efficiency (LUE) model, which is a process-based model driven by remote sensing and climate data to simulate monthly $\mathrm{NPP}_{a}[5,20,21]$, the annual $\mathrm{NPP}_{\mathrm{a}}$ was from the sum of monthly NPP in a year. In the CASA model, NPP is the product of absorbed photosynthetically active radiation (APAR) and the utilization efficiency $(\varepsilon)$. NPP is estimated as follows:

$$
N P P_{a}(x, t)=\operatorname{APAR}(x, t) \times \varepsilon(x, t),
$$

where $x$ stands for the spatial location and $t$ is the corresponding time; APAR $(x, t)$ represents the photosynthetically active radiation absorbed by vegetation of pixel $x$ in $t$ time $\left(\mathrm{MJ} \mathrm{m}^{-2}\right) ; \varepsilon(x, t)$ is the actual light-use efficiency of pixel $x$ in $\mathrm{t}$ time $\left(\mathrm{g} \mathrm{C} \mathrm{MJ}^{-1}\right)$. The detailed parameters and calculative process on the CASA model are given in the Supplementary Material. 
The climatic NPP model was developed according to a local evapotranspiration model and eco-physiological features [22], which was used to calculate the $\mathrm{NPP}_{\mathrm{p}}$ as follows:

$$
\begin{gathered}
N P P_{p}=R I^{2} \times \frac{P \times\left(1+R I+R I^{2}\right)}{(1+R I) \times\left(1+R I^{2}\right)} \times E x p(-\sqrt{9.87+6.25 \times R I}), \\
R I=\left(0.629+0.237 \times P E R-0.00313 \times P E R^{2}\right)^{2}, \\
P E R=\frac{T_{\mathrm{a}} \times 58.93}{P_{\mathrm{a}}},
\end{gathered}
$$

where $R I$ stands for the radiative index of dryness; PER represents the potential evapotranspiration rate which was determined by the combination of $P_{a}$ and $T_{a}\left(P_{a}\right.$ and $T_{a}$ are the annual precipitation $(\mathrm{mm})$ and annual mean temperature $\left({ }^{\circ} \mathrm{C}\right)$ ).

The $\mathrm{NPP}_{\mathrm{h}}$ can explain the variations of $\mathrm{NPP}_{\mathrm{a}}$ which caused by human activities. We calculated $\mathrm{NPP}_{\mathrm{h}}$ as follows [23]:

$$
N P P_{h}=N P P_{p}-N P P_{a} .
$$

Therefore, a positive or negative $\mathrm{NPP}_{\mathrm{h}}$ value can be used to identify an NPP loss or increment induced by human activities.

\subsubsection{Assessment of the NPP Changing Trends}

We used a simple linear regression model to analyze the $\mathrm{NPP}_{\mathrm{a}}, \mathrm{NPP}_{\mathrm{p}}$ and $\mathrm{NPP}_{\mathrm{h}}$ trends, namely, the relationship between the dependent and independent variables [24]. The slope of the trend line in the multi-year regression equation for a single pixel stands for the interannual variation rate. The equation is as follows:

$$
\text { Slope }=\frac{m \times \sum_{\mathrm{i}=1}^{m}\left(i \times N P P_{i}\right)-\sum_{i=1}^{m} i \times \sum_{i=1}^{m} N P P_{i}}{m \times \sum_{i=1}^{m} i^{2}-\left(\sum_{i=1}^{m} i\right)^{2}},
$$

where slope is the interannual variation rate of $\mathrm{NPP}_{\mathrm{a}}, \mathrm{NPP}_{\mathrm{p}}$ and $\mathrm{NPP}_{\mathrm{h}} ; \mathrm{n}$ is the number of years simulated; $i=1,2, \ldots 16$ are the years from 2001 to 2016, and $N P P_{i}$ is the annual values of $\mathrm{NPP}_{\mathrm{a}}$, $\mathrm{NPP}_{\mathrm{p}}$ and $\mathrm{NPP}_{\mathrm{h}}$ in year $i$.

Positive slope of $\mathrm{NPP}_{\mathrm{a}}$ indicates an increasing trend, and negative slope shows a decreasing trend. Also, the values of slope for $\mathrm{NPP}_{\mathrm{p}}$ and $\mathrm{NPP}_{\mathrm{h}}$ suggest that climate change and human activities have a positive or negative effect on grassland recovery.

Based on the result of linear trends in $\mathrm{NPP}_{\mathrm{a}}, \mathrm{NPP}_{\mathrm{p}}$ and $\mathrm{NPP}_{\mathrm{h}}$, six scenarios were established to identify the reasons for NPP change (Table 1). The situation of $\mathrm{SNPP}_{\mathrm{a}}>0$ showed that grassland restoration occurred and vice versa.

Table 1. Six scenarios of climate and human activities on grassland restoration and degradation.

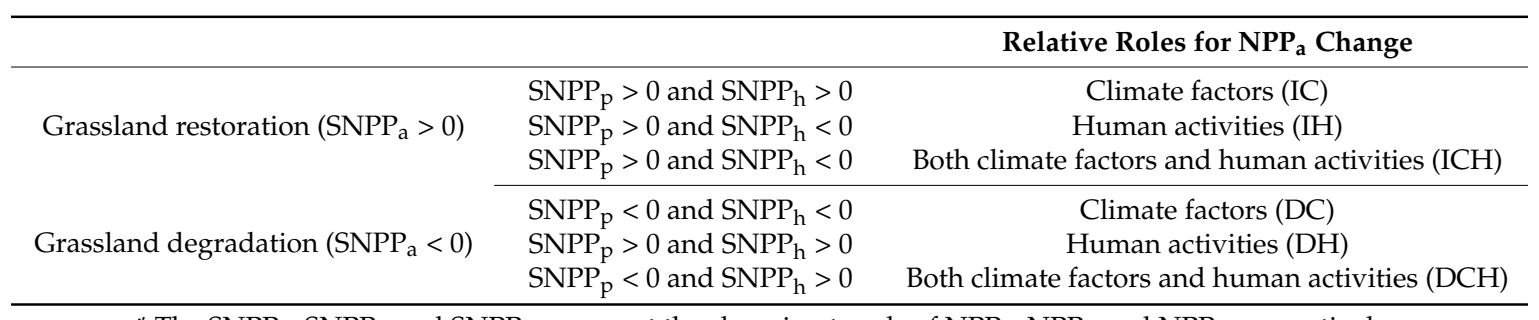

* The $\mathrm{SNPP}_{\mathrm{a}}, \mathrm{SNPP}_{\mathrm{p}}$ and $\mathrm{SNPP}_{\mathrm{h}}$ represent the changing trends of $\mathrm{NPP}_{\mathrm{a}}, \mathrm{NPP}_{\mathrm{p}}$ and $\mathrm{NPP}_{\mathrm{h}}$, respectively.

The driving forces were divided into (Table 1): increased $\mathrm{NPP}_{\mathrm{a}}$ on account of climatic factors (IC); increased NPP $\mathrm{P}_{\mathrm{a}}$ on account of human activities $(\mathrm{IH})$; increased $\mathrm{NPP}_{\mathrm{a}}$ on account of both climatic factors 
and human activities (ICH); decreased $\mathrm{NPP}_{\mathrm{a}}$ on account of climatic factors (DC); decreased $\mathrm{NPP}_{\mathrm{a}}$ on account of human activities (DH); and decreased NPP a on account of both climatic factors and human activities (DCH).

\subsubsection{Correlation Analysis}

We use a simple correlation coefficient to investigate the correlation between $\mathrm{NPP}_{\mathrm{a}}$ and precipitation, $\mathrm{NPP}_{\mathrm{a}}$ and temperature. It can be calculated by the following formula:

$$
r_{x y}=\frac{\sum_{i=1}^{n}\left(x_{i}-\bar{x}\right)\left(y_{i}-\bar{y}\right)}{\sqrt{\sum_{i=1}^{n}\left(x_{i}-\bar{x}\right)^{2} \sum_{i=1}^{n}\left(y_{i}-\bar{y}\right)^{2}}}
$$

where $i=1,2, \ldots 16$ are the years from 2001 to 2016; $\mathrm{n}$ is the sum of year; $x_{i}$ represents the NPPa of the $i$ th year; and $y_{i}$ represents the precipitation or temperature of the $i$ th year; $\bar{x}$ is the mean $\mathrm{NPP}_{\mathrm{a}}$ of 16 years, $\bar{y}$ is the mean precipitation or temperature of 16 years.

\section{Results}

\subsection{Changes of $N P P_{a}$}

The mean annual NPP $\mathrm{a}_{\mathrm{a}}$ had high values in the Yangtze, Yellow, Lancang river basins and Qilian mountains and diminished gradually to the northwest, with low values in most of the Qaidam basin (Figure 3a). The entire grassland had a mean annual $\mathrm{NPP}_{\mathrm{a}}$ value of $114.27 \mathrm{~g} \mathrm{C} \mathrm{m}^{-2}$ year $^{-1}$, ranging from 0 to $237.47 \mathrm{~g} \mathrm{C} \mathrm{m}^{-2}$ year $^{-1}$. By contrast, six grassland types displayed spatio-temporal significant differences (Figure 3).

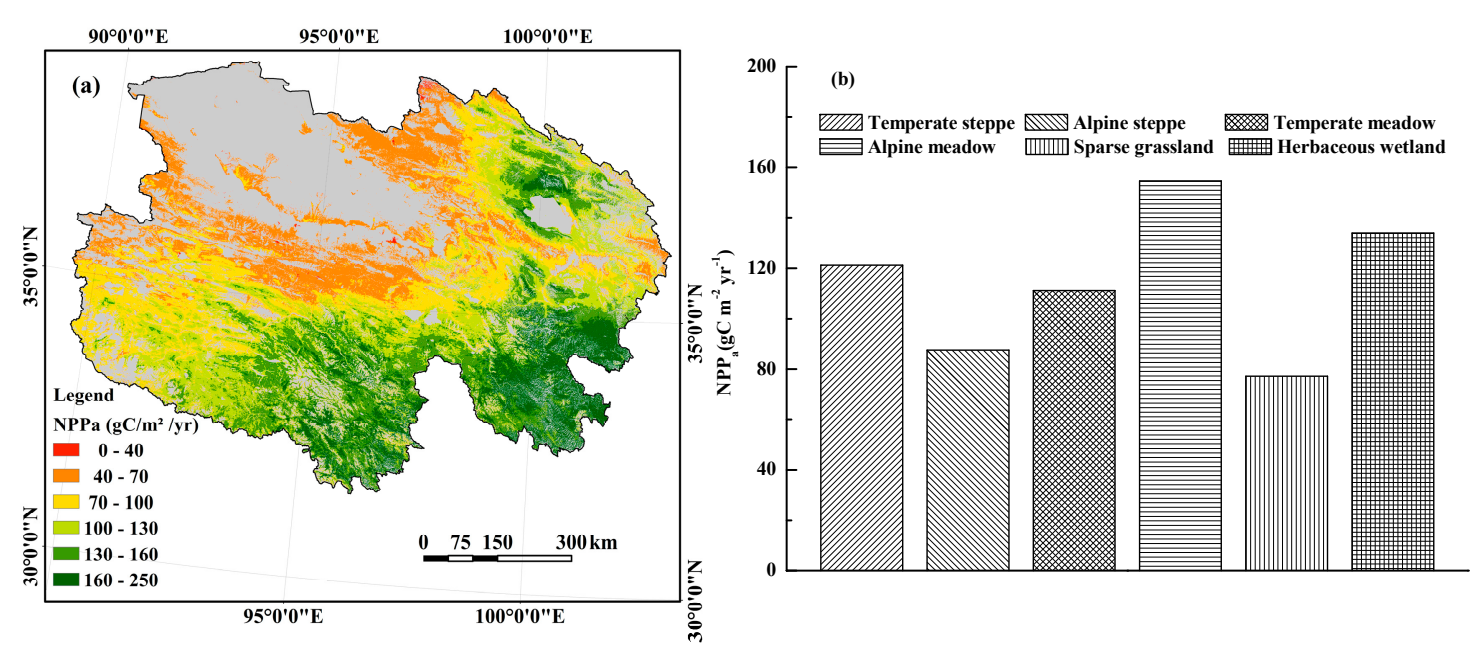

Figure 3. Spatial pattern of the mean annual (a) and $\mathrm{NPP}_{\mathrm{a}}$ for the different grassland types (b) from 2001 to 2016 in Qinghai province.

Alpine meadow is located in the source region of Yangtze, Yellow, Lancang river basins and Qilian mountains, and which had an annual mean NPP value of $155.63 \mathrm{~g} \mathrm{C} \mathrm{m}^{-2}$, where the peak and bottom mean NPP occurred in 2015 and 2013, reaching $170.37 \mathrm{~g} \mathrm{C} \mathrm{m}^{-2}$ year $^{-1}$ and $143.21 \mathrm{~g} \mathrm{C} \mathrm{m}^{-2}$ year $^{-1}$, respectively. While the sparse grassland in Qaidam basin had the lowest $\mathrm{NPP}_{\mathrm{a}}$, its annual mean value was only $77.16 \mathrm{~g} \mathrm{C} \mathrm{m}^{-2}$. For herbaceous wetland in the western Yellow river basin and middle Qilian mountains, the mean annual value of $\mathrm{NPP}_{\mathrm{a}}$ was $133.98 \mathrm{~g} \mathrm{C} \mathrm{m}^{-2}$, which was second only to alpine meadow. The temperate steppe in the southwest, northwest and middle Qinghai had a mean annual $\mathrm{NPP}_{\mathrm{a}}$ of $121.25 \mathrm{~g} \mathrm{C} \mathrm{m}^{-2}$ year $^{-1}$, where the peak and bottom mean $\mathrm{NPP}_{\mathrm{a}}$ also occurred in 
2015 and 2013, reaching $132.64 \mathrm{~g} \mathrm{C} \mathrm{m}^{-2}$ year $^{-1}$ and $112.11 \mathrm{~g} \mathrm{C} \mathrm{m}^{-2}$ year $^{-1}$, respectively. Temperate meadow is distributed around Qilian mountains and Qinghai lake and had an annual NPP $\mathrm{a}_{\mathrm{a}}$ value of $114.27 \mathrm{~g} \mathrm{C} \mathrm{m}^{-2}$. Alpine steppe is located in the Qiang Tang plateau, Qaidam basin, northwest of the Yangtze river basin, and west of the Qilian mountains, and is the transitional zone between the arid and alpine regions. The mean annual $\mathrm{NPP}_{\mathrm{a}}$ was $87.44 \mathrm{~g} \mathrm{C} \mathrm{m}^{-2}$, and the peak mean $\mathrm{NPP}_{\mathrm{a}}$ was $95.25 \mathrm{~g} \mathrm{C} \mathrm{m}^{-2}$ year $^{-1}$ and the bottom mean NPP $79.09 \mathrm{~g} \mathrm{C} \mathrm{m}^{-2}$ year $^{-1}$.

\subsection{Trends in $N P P_{a}, N P P_{p}$, and $N P P_{h}$.}

Spatial patterns of the trends and changing rate in $\mathrm{NPP}_{\mathrm{a}}, \mathrm{NPP}_{\mathrm{p}}$, and $\mathrm{NPP}_{\mathrm{h}}$ for different grassland types were depicted in Figure 4. Except for areas, such as Qinghai Lake Basin, south of Lancang river basin and east of agricultural regions, $\mathrm{NPP}_{\mathrm{a}}$ displayed an increasing trend in other regions (Figure 4a), accounting for $83.49 \%$ of the total grassland. The trends in $\mathrm{NPP}_{\mathrm{p}}$ exhibited a gradually diminishing trend moving from the south of Yellow and Yangtze river basins to the northwest. Qilian mountains and Qinghai Lake Basin also showed high $\mathrm{NPP}_{\mathrm{p}}$ values (Figure $4 \mathrm{~b}$ ). $\mathrm{NPP}_{\mathrm{h}}$ exhibited a similar trend and spatial pattern to $\mathrm{NPP}_{\mathrm{p}}$ from 2001 to 2016, and the annual increment of $\mathrm{NPP}_{\mathrm{p}}$ was $0.13 \mathrm{~g} \mathrm{C} \mathrm{m}^{-2}$, which was greater than $\mathrm{NPP}_{\mathrm{h}}$ (Figure 4c). The areas that underwent a significant increasing trend in $\mathrm{NPP}_{\mathrm{p}}$ and $\mathrm{NPP}_{\mathrm{h}}$ were in the Qilian mountains, south of Yellow river basin, southeast of Yangtze river basin, where alpine meadow was the dominant vegetation. The increasing area of $\mathrm{NPP}_{\mathrm{p}}$ and $\mathrm{NPP}_{\mathrm{h}}$ reached $62.56 \%$ and $68.55 \%$ of the total grassland area. These characteristics of $\mathrm{NPP}_{\mathrm{a}}, \mathrm{NPP}_{\mathrm{p}}$, and $\mathrm{NPP}_{\mathrm{h}}$ not only showed the spatial heterogeneity of climate and terrain, as well as the gradients of the humidity and temperature, but also reflected the intensity of human activities in Qinghai province.
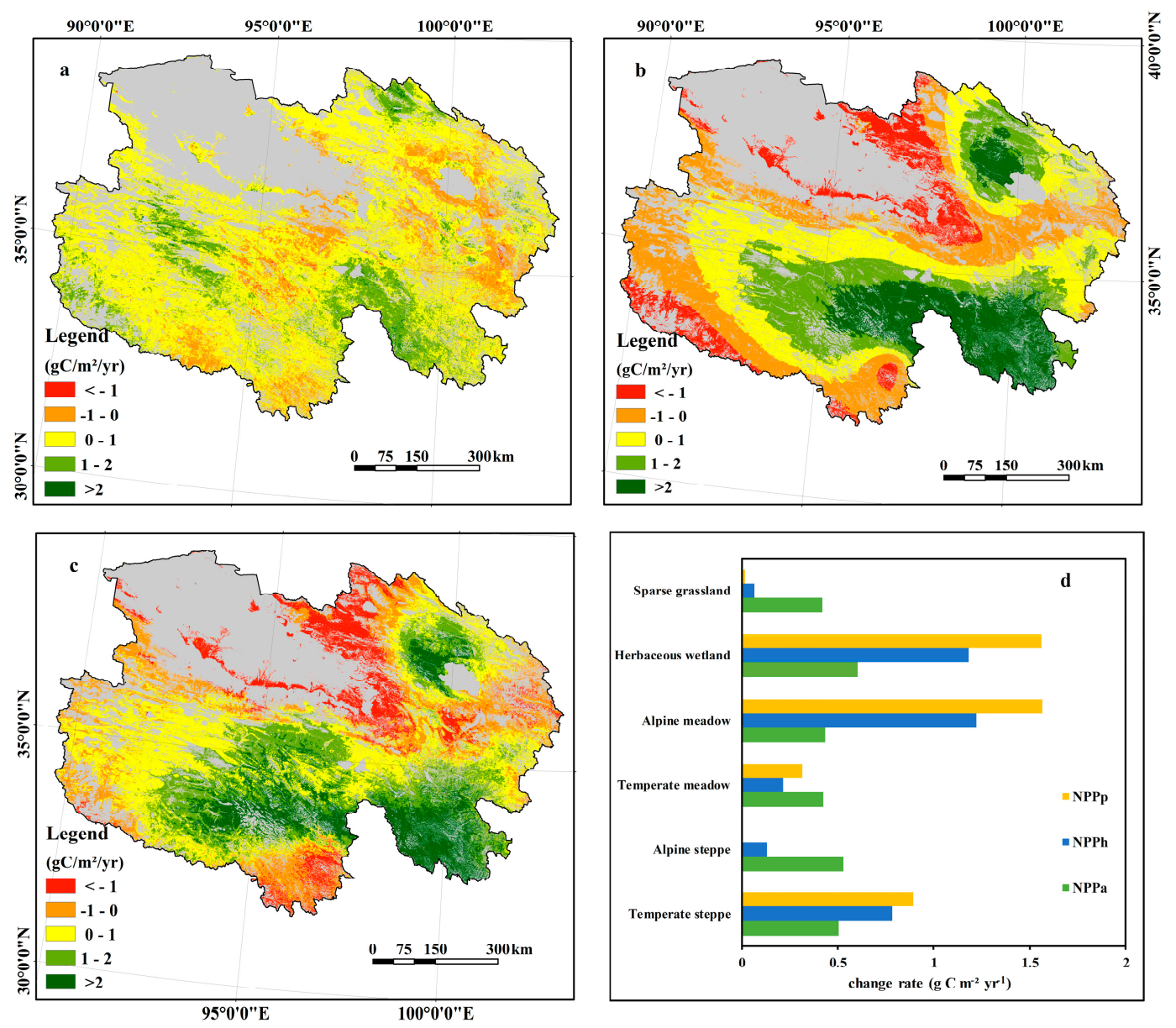

Figure 4. Spatial patterns of the changing trends for $(\mathbf{a}) \mathrm{NPP}_{\mathrm{a}},(\mathbf{b}) \mathrm{NPP}_{\mathrm{p}}$, and (c) $\mathrm{NPP}_{\mathrm{h}}$ for the different grassland types (d) from 2001 to 2016 in Qinghai province. 3.3. The reasons for $\mathrm{NPP}_{\mathrm{a}}$ change. 
Compared to temperate meadow and sparse grassland, herbaceous wetland experienced a significant increasing NPP trend, closely followed by alpine steppe and temperate steppe, and then was alpine meadow, with an annual increment of $0.61 \mathrm{~g} \mathrm{C} \mathrm{m}^{-2}, 0.53 \mathrm{~g} \mathrm{C} \mathrm{m}^{-2}, 0.51 \mathrm{~g} \mathrm{C} \mathrm{m}^{-2}$ and $0.43 \mathrm{~g} \mathrm{C} \mathrm{m}^{-2}$, accounting for $84.89 \%, 87.06 \%, 82.27 \%$ and $77.13 \%$ of their own area, respectively. Alpine meadow and herbaceous wetland increased significantly in $\mathrm{NPP}_{\mathrm{p}}$ at an annual increase of $1.56 \mathrm{~g} \mathrm{C} \mathrm{m}^{-2}$, and temperate steppe and alpine steppe increased in $\mathrm{NPP}_{\mathrm{p}}$ with an annual increment of $0.89 \mathrm{~g} \mathrm{C} \mathrm{m}^{-2}$ and $0.32 \mathrm{~g} \mathrm{C} \mathrm{m}^{-2}$, respectively, while $\mathrm{NPP}_{\mathrm{p}}$ of alpine steppe and sparse grassland had a slightly increasing trend. Similar to $\mathrm{NPP}_{\mathrm{p}}$, alpine meadow and herbaceous wetland also had higher values in $\mathrm{NPP}_{\mathrm{h}}$ than other grassland types, increasing by $1.22 \mathrm{~g} \mathrm{C} \mathrm{m}^{-2}$ year $^{-1}$ and $1.18 \mathrm{~g} \mathrm{C} \mathrm{m}^{-2}$ year ${ }^{-1}$, closely followed by temperate steppe with an annual increment of $0.78 \mathrm{~g} \mathrm{C} \mathrm{m}^{-2}$, then temperate meadow, alpine steppe and sparse grassland. Meanwhile, the difference of temperate steppe between $\mathrm{NPP}_{\mathrm{a}}$ and $\mathrm{NPP}_{\mathrm{p}}$ was larger than other grassland types, the herbaceous wetland had the lowest difference.

\subsection{Reasons for $N P P_{a}$ Changes}

The trends in $\mathrm{NPP}_{\mathrm{a}}, \mathrm{NPP}_{\mathrm{p}}$ and $\mathrm{NPP}_{\mathrm{h}}$ were superimposed to identify the contributions of climate and human activities to grassland restoration and degradation (Figure 5). The area of IC was distributed in Qilian mountains, Yangtze river basin and south of Yellow river basin, accounting for $47.08 \%$ of the total grassland. By contrast, the area of DC occurred in the Lancang river basin and the south of Qinghai lake with a proportion of 3.81\% of the total grassland. The area of IH was distributed in Qaidam basin, Qiangtang plateau, Lancang river basin, north of Yellow river basin and west of Qilian mountains, accounting for $21.74 \%$ of the total grassland, while DH area percentage was $9.78 \%$, distributing in the northwest of Yellow river basin and around Qinghai lake. The areas of ICH and DCH only accounted for $5.79 \%$ and $2.77 \%$ of the total grassland, which was mainly found in the north of Lancang river basin, the northwest of Qilian mountains, and the parts of Qaidam basin.

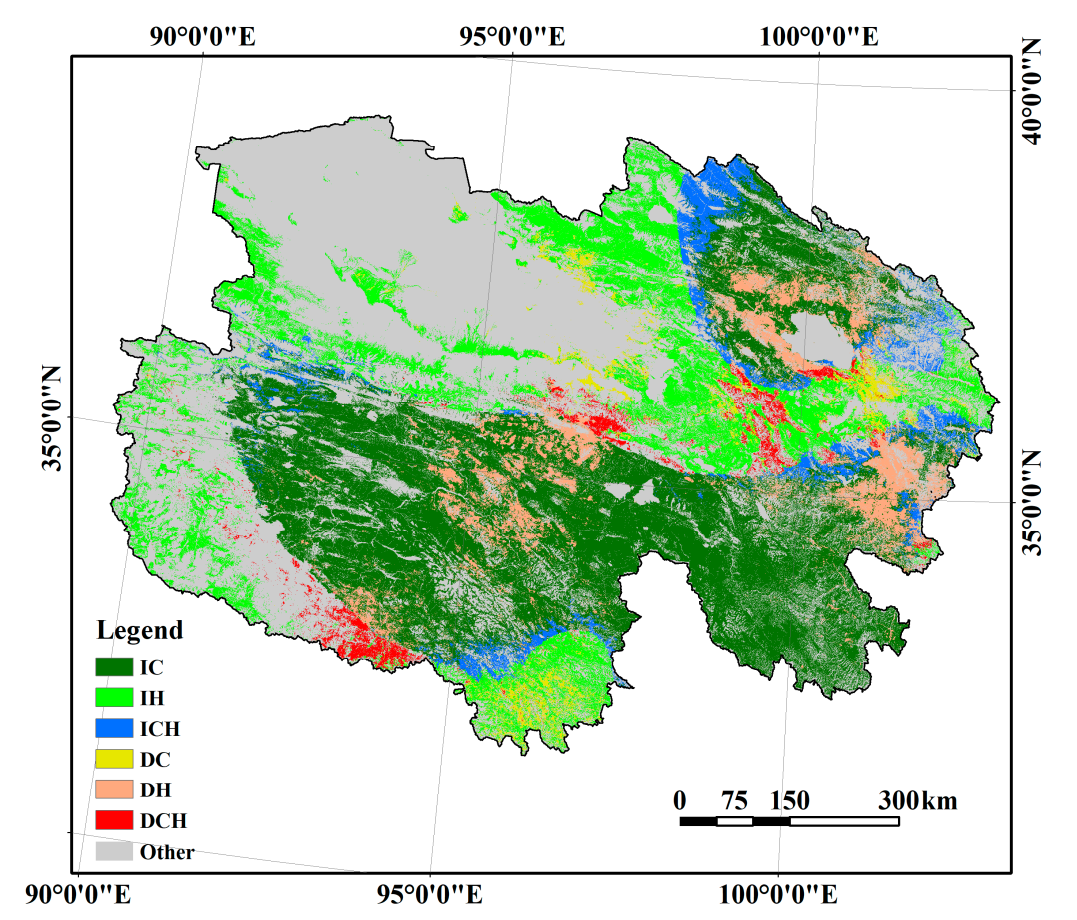

Figure 5. Spatial patterns of driving forces for $\mathrm{NPP}_{\mathrm{a}}$ changes from 2001 to 2016.

\subsection{Impacts of Climate Factors on $N P P_{a}$ Changes}

From 2001 to 2016, the mean temperature exhibited a slightly increasing trend, with an annual mean increment of $0.02{ }^{\circ} \mathrm{C}$, while the mean precipitation experienced a slightly decreasing trend with 
the value of $0.76 \mathrm{~mm}$ year ${ }^{-1}$ (Figure 6). The temperature showed a significant increasing trend in the Yangtze river basin, west of the Yellow river basin, Qilian mountain and Qinghai Lake Basin where $\mathrm{NPP}_{\mathrm{a}}$ and $\mathrm{NPP}_{\mathrm{p}}$ manifested a slightly increasing trend. The precipitation that showed a significant increasing trend mainly distributed in the south Yangtze river basin and the Yellow river basin, as well as the Qilian mountains.
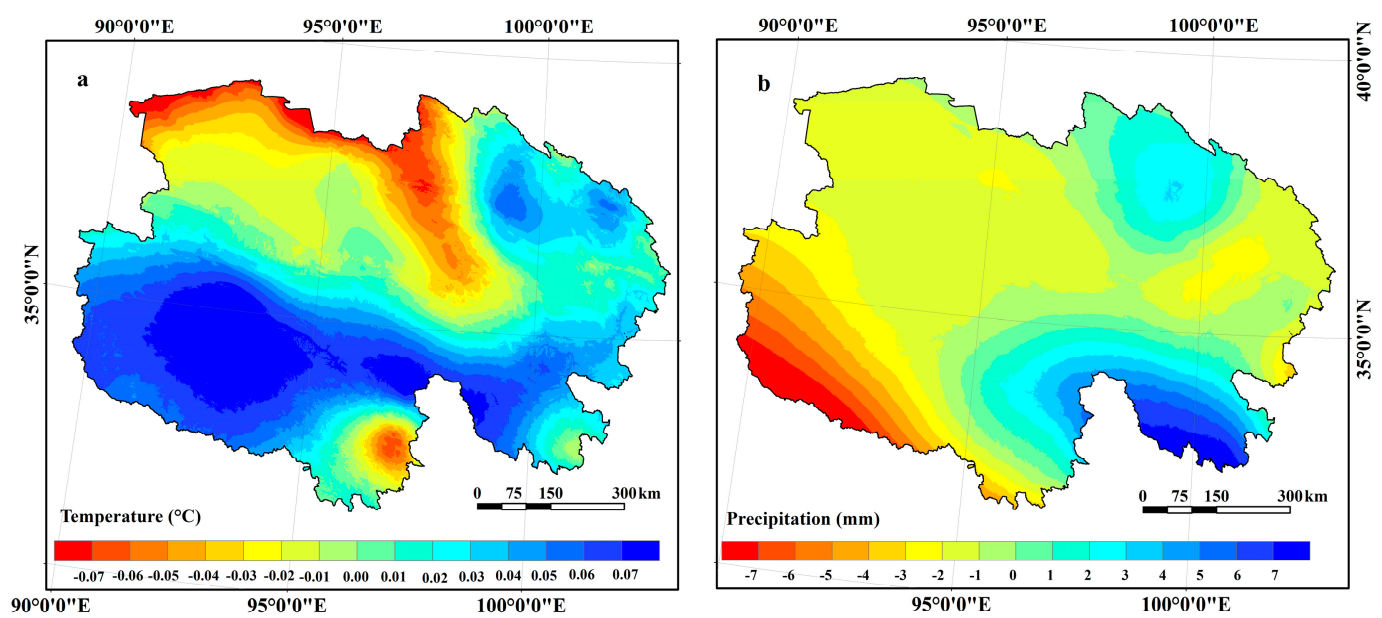

Figure 6. Spatial distribution of the trends for (a) the annual mean temperature and (b) the annual total precipitation from 2001 to 2016 in Qinghai province.

The average correlation coefficients between temperature and $\mathrm{NPP}_{\mathrm{a}}$, precipitation and $\mathrm{NPP}_{\mathrm{a}}$ over the entire region were $0.165 \mathrm{~g} \mathrm{C} \mathrm{m}^{-2}$ year $^{-2}$ and $0.014 \mathrm{~g} \mathrm{C} \mathrm{m}^{-2}$ year $^{-2}$, respectively (Figure 7). The regions with significant positive correlation coefficients were mainly distributed in the Qiang Tang plateau, the north of Yangtze and Yellow river basin, and the northwest of Qilian mountains. While the correlation coefficients between $\mathrm{NPP}_{\mathrm{a}}$ and temperature were negative in most parts of the southeastern Qinghai province. However, the correlation coefficients between $\mathrm{NPP}_{\mathrm{a}}$ and precipitation showed unobvious spatio-temporal differences, the correlation coefficients ranged from -0.1 to 0.1 in the most regions, only with a high value in the northwestern Yellow River basin.
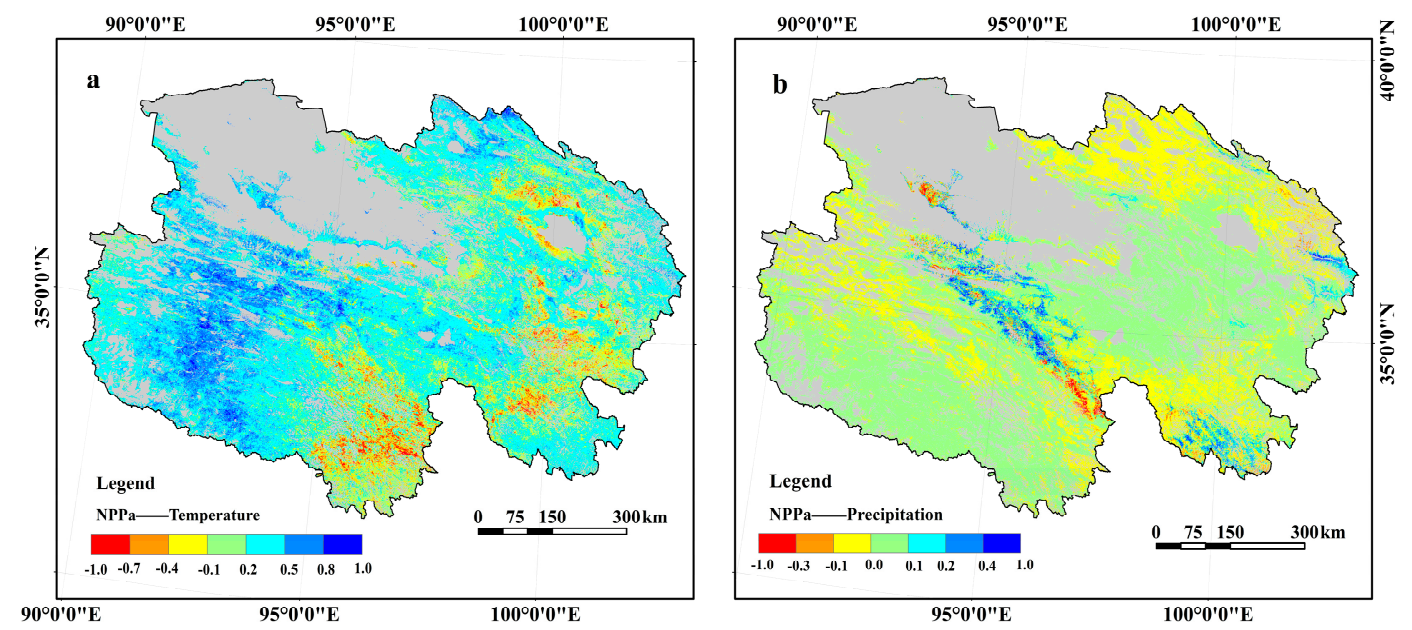

Figure 7. Spatial patterns of the correlation coefficients between $\mathrm{NPP}_{\mathrm{a}}$ and temperature, $\mathrm{NPP}_{\mathrm{a}}$ and precipitation from 2001 to 2016.

\section{Discussion}

This study analyzed the spatiotemporal dynamics of $\mathrm{NPP}_{\mathrm{a}}$ across different grassland types, such as temperate steppe, alpine steppe, temperate meadow, alpine meadow, sparse grassland and 
herbaceous wetland. The results provided a new understanding of grassland dynamics in Qinghai province in recent decades. In this study, grassland $\mathrm{NPP}_{\mathrm{a}}$ exhibited an increasing trend in Qinghai province from 2001 to 2016, and the increasing rates were different among six typical grassland types. By contrast, several previous studies found that grassland had been restored at different levels in Qinghai province in recent decades $[4,12]$. These findings indicated that selecting different study areas and time intervals can result in varying conclusions [25], our results are similar to those of previous researches.

Climate change has a profound effect on vegetation variability in the world [26]. Qinghai province as an important part of the Tibetan Plateau belongs to high-altitude regions, the grassland is particularly sensitive to climate change and is characterized by extremely fragile ecosystems [27-29]. Thus, it is necessary to investigate the correlation coefficients of the precipitation and temperature with $\mathrm{NPP}_{\mathrm{a}}$ for each pixel [30].

Although the understanding of the grassland response to climate change showed discrepancies among scholars, due to the different vegetation types, study periods and climate conditions of the study area, a general consensus has been reached that temperatures showed an increasing trend in the last few decades and the trend of precipitation was highly dependent on the location of space in the Tibetan Plateau [10,31-33]. A previous study found that temperature had a more obvious effect for vegetation growth than did moisture in the Yangtze, Yellow and Lancang river basin [34], mostly because increased temperature might have an impact on variabilities of growing season, phenology and photosynthesis, this would further accelerate carbon cycle and improve capacity of vegetation production [35]. Besides, the climate in the Yangtze river basin, Qilian mountains and west of the Yellow river basin is characterized by the lower temperature and much richer rainfall than other regions, suggesting that the impact of moisture on vegetation is much weaker than that of temperature $[9,25]$. The previous conclusions might be an explanation for our results. The temperature would decrease when the precipitation increased [9], which might lead to a decrease in vegetation photosynthesis activity [36].

Grazing and human-induced land-cover variabilities were considered as the main human activities for grassland degradation, especially for grazing [27,37]. Since the 1960s, with the rapid development of the economy, the number of livestock has increased significantly in Qinghai province $[27,38]$. Tibetans are the most dominant residents in this region, who depend on animal husbandry for their livelihood. The overgrazing occurred along with an increasement of livestock numbers, which would exceed the carrying capacity of the grassland. Grassland degraded seriously, due to the pursuit of short-term benefits of Tibetans and defective protection and management measures before $2000[38,39]$. The livestock numbers showed an increasing trend in the whole region after 2000 (Figure 8), which might offset the positive impacts of climate factor especially for the regions of IC and ICH (Figure 5). The implementation of ecological protection projects and constructions (Grazing Withdrawal Program, Grain to Green Program, ecological immigration and so on) included multiple measures like banning and rotational grazing, grass planting and fencing degrading areas so far as to converting rangeland to cultivated pasture, which had positive contributions to grassland restoration $[40,41]$. Thus, both human activities and climate change produced a favorable impact on grassland restoration from 2001 to 2016, it can explain why NPPa and livestock numbers showed an increasing trend during this period. Although overgrazing would lead to grassland degradation, reasonable grazing intensity and effective protection measures might facilitate grassland productivity. 


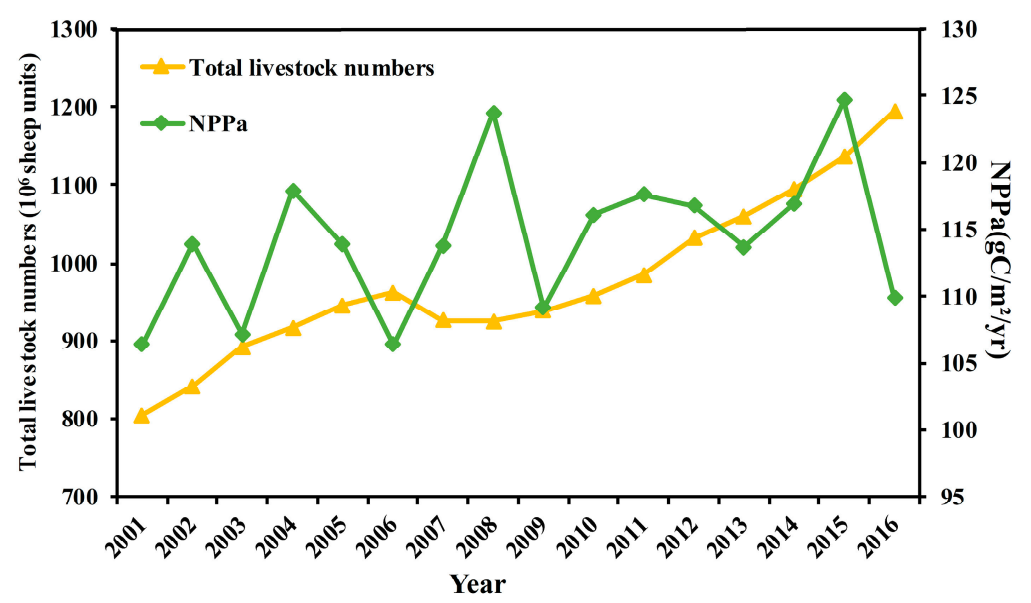

Figure 8. The dynamics of $\mathrm{NPP}_{\mathrm{a}}$ and livestock numbers from 2001 to 2016 in Qinghai province.

\section{Conclusions}

We analyzed the spatiotemporal dynamics of $\mathrm{NPP}_{\mathrm{a}}$ across different grassland types. Then, the possible reasons for grassland change were analyzed. From 2001 to 2016, the average NPP $\mathrm{a}_{\mathrm{a}}$ Qinghai province showed a fluctuation, presented a generally increasing trend. The mean value of $\mathrm{NPP}_{\mathrm{a}}$ was $114.27 \mathrm{~g} \mathrm{C} \mathrm{m}^{-2}$ year $^{-1}$, the increase rate was $0.47 \mathrm{~g} \mathrm{~cm}^{-2}$ year $^{-1}$. The area was characterized by significant spatial heterogeneity, with high $\mathrm{NPP}_{\mathrm{a}}$ values in the Qilian mountains and the Three-River Headwaters region, with low $\mathrm{NPP}_{\mathrm{a}}$ values in the Qaidam basin. The annual mean $\mathrm{NPP}_{\mathrm{a}}$ showed discrepancies among alpine meadow, herbaceous wetland, temperate steppe, temperate meadow, alpine steppe and sparse grassland, with values of 155.63, 133.98, 121.25, 114.27, 87.44 and $77.16 \mathrm{~g} \mathrm{C} \mathrm{m}^{-2}$ year $^{-1}$, respectively. During the study period, the increasing area of $\mathrm{NPP}_{\mathrm{a}}, \mathrm{NPP}_{\mathrm{p}}$ and $\mathrm{NPP}_{\mathrm{h}}$ accounted for $83.49 \%, 62.56 \%$ and $68.55 \%$ of the total grassland, respectively. Herbaceous wetland had the highest change rate, closely followed by alpine steppe, temperate steppe, alpine meadow, temperate meadow and sparse grassland. The largest area of restoration mainly impacted by climate change reached $47.08 \%$ of the total grassland area, with human activities accounting for $21.74 \%$, and the rest $5.79 \%$ was caused equally by both of them. By contrast, the deteriorated area induced by human activities accounted for $9.78 \%$ of the total grassland, 3.81\% was caused by climate change, and the remaining $2.77 \%$ was attributed to both of them. Temperature may be a greater factor than precipitation in driving grassland change during the study period. Decreasing grazing intensity and implementing effective protection measures were favorable to grassland restoration.

Supplementary Materials: The following are available online at http:/ / www.mdpi.com/2220-9964/8/2/73/s1, the concrete calculation formula and process on CASA model.

Author Contributions: Xiaoxu Wei and Changzhen Yan designed research; Xiaoxu Wei performed research; Xiaoxu Wei analyzed data; Xiaoxu Wei wrote the paper; Wei Wei provided suggestions on the manuscript.

Funding: This research was funded by the National Key Research and Development Program of China (Grant No. 2016YFC0500201), National Natural Science Foundation of China (Grant No. 41730752 \& 41861040 ).

Acknowledgments: The authors would like to thank all anonymous reviewers and editors for their constructive comments on this paper. The authors also thank American Journal Experts (https://www.aje.com/) for editing the revised version of this manuscript.

Conflicts of Interest: The authors declare no conflict of interest.

\section{References}

1. Xu, H.J.; Wang, X.P.; Zhang, X.X. Alpine grasslands response to climatic factors and anthropogenic activities on the Tibetan plateau from 2000 to 2012. Ecol. Eng. 2016, 92, 251-259. [CrossRef]

2. Conant, R.T.; Paustian, K.; Elliott, E.T. Grassland management and conversion into grassland: Effects on soil carbon. Ecol. Appl. 2001, 11,343-355. [CrossRef] 
3. Piao, S.; Fang, J.; Ciais, P.; Peylin, P.; Huang, Y.; Sitch, S.; Wang, T. The carbon balance of terrestrial ecosystems in China. Nature 2009, 458, 1009-1013. [CrossRef] [PubMed]

4. Zhang, Y.; Zhang, C.; Wang, Z.; Chen, Y.; Gang, C.; An, R.; Li, J. Vegetation dynamics and its driving forces from climate change and human activities in the three-river source region, China from 1982 to 2012. Sci. Total Environ. 2016, 563-564, 210-220. [CrossRef] [PubMed]

5. Potter, C.S.; Randerson, J.T.; Field, C.B.; Matson, P.A.; Vitousek, P.M.; Mooney, H.A.; Klooster, S.A. Terrestrial ecosystem production: A process model based on global satellite and surface data. Glob. Biogeochem. Cycles 1993, 7, 811-841. [CrossRef]

6. Luo, L.; Ma, W.; Zhuang, Y.; Zhang, Y.; Yi, S.; Xu, J.; Long, Y.; Ma, D.; Zhang, Z. The impacts of climate change and human activities on alpine vegetation and permafrost in the Qinghai-Tibet engineering corridor. Ecol. Indic. 2018, 93, 24-35. [CrossRef]

7. Chen, B.; Zhang, X.; Tao, J.; Wu, J.; Wang, J.; Shi, P.; Zhang, Y.; Yu, C. The impact of climate change and anthropogenic activities on alpine grassland over the Qinghai-Tibet plateau. Agric. For. Meteorol. 2014, 189-190, 11-18. [CrossRef]

8. Li, Q.; Zhang, C.; Shen, Y.; Jia, W.; Li, J. Quantitative assessment of the relative roles of climate change and human activities in desertification processes on the Qinghai-Tibet plateau based on net primary productivity. Catena 2016, 147, 789-796. [CrossRef]

9. Wang, Z.; Zhang, Y.; Yang, Y.; Zhou, W.; Gang, C.; Zhang, Y.; Li, J.; An, R.; Wang, K.; Odeh, I.; et al. Quantitative assess the driving forces on the grassland degradation in the Qinghai-Tibet plateau, in China. Ecol. Inform. 2016, 33, 32-44. [CrossRef]

10. Wang, S.; Zhang, B.; Yang, Q.; Chen, G.; Yang, B.; Lu, L.; Shen, M.; Peng, Y. Responses of net primary productivity to phenological dynamics in the Tibetan plateau, China. Agric. For. Meteorol. 2017, 232, 235-246. [CrossRef]

11. Liu, C.; Dong, X.; Liu, Y. Changes of NPP and their relationship to climate factors based on the transformation of different scales in Gansu, China. Catena 2015, 125, 190-199. [CrossRef]

12. Lieth, H. Modeling the Primary Productivity of the World. In Primary Productivity of the Biosphere; Leith, H., Whittaker, R.H., Eds.; Springer: Berlin, Germany, 1975; pp. 237-263.

13. Liang, T.G.; Yang, S.; Feng, Q.; Liu, B.; Zhang, R.; Huang, X.; Xie, H. Multi-factor modeling of above-ground biomass in alpine grassland: A case study in the three-river headwaters region, China. Remote Sens. Environ. 2016, 186, 164-172. [CrossRef]

14. Shao, Q.; Fan, J.; Liu, J.; Huang, L.; Cao, W.; Liu, L. Target-based assessment on effects of first-stage ecological conservation and restoration project in three-river source region, China and policy recommendations. Bull. Chin. Acad. Sci. 2017, 32, 35-44.

15. Gao, Y.; Zhou, X.; Wang, Q.; Wang, C.; Zhan, Z.; Chen, L.; Yan, J.; Qu, R. Vegetation net primary productivity and its response to climate change during 2001-2008 in the Tibetan plateau. Sci. Total Environ. 2013, 444, 356-362. [CrossRef] [PubMed]

16. Piao, S.L.; Fang, J.Y.; Guo, Q.H. Application of CASA model to the estimation of Chinese terrestrial net primary productivity. Acta Phytoecol. Sin. 2001, 25, 603-608, (In Chinese with English Abstract).

17. Zhu, W.Q.; Pan, Y.Z.; Long, Z.H.; Chen, Y.H.; Li, J.; Hu, H.B. Estimating net primary productivity of terrestrial vegetation based on GIS and RS: A case study in inner Mongolia, China. J. Remote Sen. 2004, 9, 300-307.

18. Scurlock, J.M.; Cramer, W.; Olson, R.J.; Parton, W.J.; Prince, S.D. Terrestrial NPP: Toward a consistent data set for global model evaluation. Ecol. Appl. 1999, 9, 913-919. [CrossRef]

19. Yang, Y.; Fang, J.; Ji, C.; Han, W. Above-and belowground biomass allocation in Tibetan grasslands. Veg. Sci. 2009, 20, 177-184. [CrossRef]

20. Monteith, J.L. Solar radiation and productivity in tropical ecosystems. J. Appl. Ecol. 1972, 9, 747-766. [CrossRef]

21. Potter, C.S.; Klooster, S.; Brooks, V. Interannual variability in terrestrial net primary production: Exploration of trends and controls on regional to global scales. Ecosystems 1999, 2, 36-48. [CrossRef]

22. Zhou, G.; Zhang, X. Study on npp of natural vegetation in china under global climate change. Acta Phytoecol. Sin. 1996, 20, 11-19, (In Chinese with English Abstract). 
23. Haberl, H.; Erb, K.H.; Krausmann, F.; Gaube, V.; Bondeau, A.; Plutzar, C.; Gingrich, S.; Lucht, W.; Fischer-Kowalski, M. From the cover: Quantifying and mapping the human appropriation of net primary production in earth's terrestrial ecosystems. Proc. Natl. Acad. Sci. USA 2007, 104, 12942-12947. [CrossRef] [PubMed]

24. Stow, D.; Daeschner, S.; Hope, A.; Douglas, D.; Petersen, A.; Myneni, R.; Zhou, L.; Oechel, W. Variability of the seasonally integrated normalized difference vegetation index across the north slope of Alaska in the 1990s. Int. J. Remote Sens. 2003, 24, 1111-1117. [CrossRef]

25. Xu, W.; Gu, S.; Zhao, X.Q.; Xiao, J.; Tang, Y.; Fang, J.; Zhang, J.; Jiang, S. High positive correlation between soil temperature and NDVI from 1982 to 2006 in alpine meadow of the three-river source region on the Qinghai-Tibetan Plateau. Int. J. Appl. Earth Obs. Geoinf. 2011, 13, 528-535. [CrossRef]

26. Churkina, G.; Running, S.W. Contrasting climatic controls on the estimated productivity of global terrestrial biomes. Ecosystems 1998, 1, 206-215. [CrossRef]

27. Du, M.; Kawashima, S.; Yonemura, S.; Zhang, X.; Chen, S. Mutual influence between human activities and climate change in the Tibetan Plateau during recent years. Glob. Planet. Chang. 2004, 41, 241-249. [CrossRef]

28. Cheng, G.; $\mathrm{Wu}$, T.H. Responses of permafrost to climate change and their environmental significance, Qinghai-Tibet Plateau. J. Geophy. Res. Earth Surf. 2007, 112, 1-10. [CrossRef]

29. Wang, G.X.; Wang, Y.B.; Li, Y.S.; Cheng, H.Y. Influences of alpine ecosystem responses to climatic change on soil properties on the Qinghai-Tibet Plateau, China. Catena 2007, 70, 506-514. [CrossRef]

30. Crabtree, R.; Potter, C.; Mullen, R.; Sheldon, J.; Huang, S.; Harmsen, J.; Rodman, A.; Jean, C. A modeling and spatio-temporal analysis framework for monitoring environmental change using NPP as an ecosystem indicator. Remote Sens. Environ. 2009, 113, 1486-1496. [CrossRef]

31. Piao, S.; Cui, M.; Chen, A.; Wang, X.; Ciais, P.; Liu, J.; Tang, Y. Altitude and temperature dependence of change in the spring vegetation green-up date from 1982 to 2006 in the Qinghai-Xizang Plateau. Agric. For. Meteorol. 2011, 151, 1599-1608. [CrossRef]

32. Heitzler, M.; Lam, J.; Hackl, J.; Adey, B.; Hurni, L. GPU-accelerated rendering methods to visually analyze large-scale disaster simulation data. J. Geovis. Spat. Anal. 2017, 1, 3. [CrossRef]

33. Shen, W.; Zhao, W.; Wang, X.; Xu, L. Ecological Carrying Capacity and Sustainable Development in Tibet; China Environmental Press: Beijing, China, 2015. (In Chinese)

34. Hu, M.Q.; Mao, F.; Sun, H.; Hou, Y.Y. Study of normalized difference vegetation index variation and its correlation with climate factors in the three-river-source region. Int. J. Appl. Earth Obs. Geoinf. 2011, 13, $24-33$. [CrossRef]

35. Ni, J. A simulation of biomes on the Tibetan Plateau and their responses to global climate change. Mt. Res. Dev. 2000, 20, 80-89. [CrossRef]

36. Hilker, T.; Lyapustin, A.I.; Tucker, C.J.; Hall, F.G.; Myneni, R.B.; Wang, Y.; Bi, J.; de Moura, Y.M.; Sellers, P.J. Vegetation dynamics and rainfall sensitivity of the Amazon. Proc. Natl. Acad. Sci. USA 2014, 111, 16041-16046. [CrossRef] [PubMed]

37. Chen, H.; Zhu, Q.; Peng, C.; Wu, N.; Wang, Y.; Fang, X.; Gao, Y.; Zhu, D.; Yang, G.; Tian, J.; et al. The impacts of climate change and human activities on biogeochemical cycles on the Qinghai-Tibetan Plateau. Glob. Chang. Biol. 2013, 19, 2940-2955. [CrossRef] [PubMed]

38. Fan, J.W.; Shao, Q.Q.; Liu, J.Y.; Wang, J.B.; Harris, W.; Chen, Z.Q.; Zhong, H.P.; Xu, X.L.; Liu, R.G. Assessment of effects of climate change and grazing activity on grassland yield in the three rivers headwaters region of Qinghai-Tibet Plateau, China. Environ. Monit. Assess. 2010, 170, 571. [CrossRef] [PubMed]

39. Ren, J.Z.; Lin, H.L. Assumed plan on grassland ecological reconstruction in the source region of Yangtse river, Yellow river and Lantsang river. Acta Pratacult. Sci. 2005, 14, 1-8, (In Chinese with English Abstract).

40. Mu, S.; Zhou, S.; Chen, Y.; Li, J.; Ju, W.; Odeh, I.O.A. Assessing the impact of restoration-induced land conversion and management alternatives on net primary productivity in inner Mongolian grassland, China. Glob. Planet. Chang. 2013, 108, 29-41. [CrossRef]

41. Fang, Y. Managing the three-rivers headwater region, china: From ecological engineering to social engineering. Ambio 2013, 42, 566-576. [CrossRef]

(C) 2019 by the authors. Licensee MDPI, Basel, Switzerland. This article is an open access article distributed under the terms and conditions of the Creative Commons Attribution (CC BY) license (http:/ / creativecommons.org/licenses/by/4.0/). 